\title{
Occlusal Characteristics of Children with Class I Malocclusion in Northeastern Brazil
}

\section{Janayne de Sousa Oliveira ${ }^{1}$, Kézia Nogueira da Costa $^{1}$, Maria Vieira de Lima Saintrain ${ }^{2 *}$, Maria da Glória Almeida Martins ${ }^{3}$}

${ }^{1}$ Dentist-surgeon - University of Fortaleza, Ceará, Brazil.

${ }^{2} \mathrm{DDs}, \mathrm{MSc}, \mathrm{PhD}$ in Dentistry in Collective Health, Professor of the Center of Science and Health and Master's Degree in Collective Health of the University of Fortaleza - UNIFOR.

${ }^{3}$ DDs. PhD. Professor of Dentistry Course - University of Fortaleza - UNIFOR

\begin{abstract}
:
Introduction: Malocclusion is an oral health condition defined as an important health problem that may lead to aesthetic dissatisfaction as well as changes in speech, breathing, posture, chewing, swallowing, disorders of the temporomandibular joint and orofacial pain.

Objective: To assess the prevalence of occlusal characteristics of schoolchildren aged 10 to 12 years with Class I malocclusion.

Methodology: Quantitative cross-sectional study with a sample of 125 schoolchildren from the city of Fortaleza, located in the state of Ceará, Northeastern Brazil. Children's parents and grandparents should also be from the same state. Children were examined by a dentist-surgeon in a dental office after prior authorization from parents/legal guardians.

Results: The most prevalent occlusal characteristics were crowding (34.4\%), biprotrusion (22.4\%) and anterior open bite (16.8\%).

Conclusion: Occlusal characteristics such as crowding, biprotrusion and anterior open bite were far more expressive than the others analyzed in the present study. The presence of malocclusion did not necessarily indicate the need for surgical intervention. However, it points out the need for preventive care by a dentistsurgeon.
\end{abstract}

Keywords: Angle Class I Malocclusion; Occlusal Characteristics; Children; Oral Health.

\section{INTRODUCTION}

Malocclusion is an oral health condition defined as an important health problem by the World Health Organization (WHO $)^{1}$ and that has been known in recent times as the disease of modern civilization ${ }^{2}$. It is a set of significant variations in growth and morphology of the dental arches that may lead to aesthetic dissatisfaction as well as changes in speech, breathing, posture, chewing, swallowing, disorders of the temporomandibular joint and orofacial pain ${ }^{3}$.

According to Angle (1899) ${ }^{4}$, in Class I malocclusion there is a harmony between jaw bones, with the molars in normal occlusion position and anterior teeth in a bad position; therefore, it is common to observe the presence of alterations such as crowding, overjet, anterior open bite, biprotrusion, among others.

The literature shows prevalence rates of malocclusion between 80 and $89 \%$ in mixed dentition, where

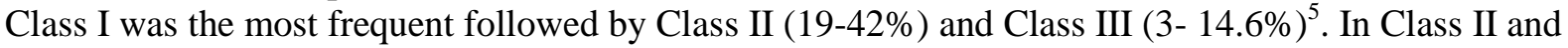
Class III malocclusion there is maxillary retraction or hypoplasia, which may or may not be associated with prognathism ${ }^{6}$.

In this context, studies have analyzed ${ }^{7,8}$ and classified ${ }^{9,10}$ malocclusions, obtaining data and providing important rates for understanding them within the oral health context.

Furthermore, it is known that malocclusion ranks third in priority among dental problems of global public health after dental caries and periodontal disease respectively ${ }^{11}$.

In this perspective, the present study aimed to assess the prevalence of occlusal characteristics of schoolchildren aged 10 to 12 years with Class I malocclusion in Northeastern Brazil. 


\section{Methodology}

This quantitative cross-sectional study originated from a research that carried out a clinical analysis of 264 schoolchildren aged 10 to 12 years from the city of Fortaleza, Ceará, Northeastern Brazil.

The clinical examination of schoolchildren was performed by a single examiner. According to Angle's classification, a total of 125 children had Class I malocclusion.

Inclusion criteria were schoolchildren born and raised in the state of Ceará whose parents and grandparents were also from the same state. Additionally, they should present Angle's Class I Molar Relationship. Patients without history of orofacial surgery or orthodontic treatment.

Clinical examination was carried out with each child after obtaining written consent from their parents/legal guardians who authorized the examination. In addition, schools also had to accept to participate in the study.

Examinations were carried out at the schools by a dentist-surgeon under natural light using a wooden tongue depressor. All schoolchildren underwent clinical examination sitting in their own chair outside the classroom.

The dental characteristics analyzed were crowding, biprotrusion, lack of space, deep bite, edge-toedge bite, overjet, spacing, anterior open bite, right side posterior crossbite, left side posterior crossbite, anterior crossbite and posterior crossbite.

The following variables were defined according to the literature ${ }^{12}$ : crowding (when there is disharmony between the size of the teeth and the space available for them); bi-protrusion (when there is proclination in the anterior region of both arches); anterior open bite (when there is no vertical overlap); spacing (when there is a lack of contact between the teeth - occurrence of localized or generalized diastema); lack of space (when the teeth in occlusion are aligned but there is not enough space for the teeth that will erupt); edge-to-edge bite (when there is no overlap between the upper and lower incisors); deep bite (when the vertical overlap between the incisors is greater than one-third of the tooth crown); maxillary protrusion (when the upper central incisors are proclined in relation to their bony base); posterior crossbite (when buccal cusps of one or more upper teeth occlude in the central fossa of one or more lower teeth; it is classified into unilateral (only one side) and bilateral (both sides).

The research that orginated the presente study was approved by the Research Ethics Committee of the University of Fortaleza under Opinion No. 272/2004.

\section{ReSUlts}

The data collected during the clinical examination of patients are described in Table 1, which shows the prevalence of occlusal characteristics of the study population. The results demonstrated that the most prevalent occlusal characteristics were - in descending order - crowding, bi-protrusion, anterior open bite and lack of space, with significant rates compared to the other characteristics listed.

Table1. Distribution of occlusal characteristics in schoolchildren with Class I malocclusion

\begin{tabular}{|l|c|c|}
\hline Intra-arch Malocclusion Relationship & $\mathrm{n}$ & $\%$ \\
\hline Crowding & 43 & $34.4 \%$ \\
\hline Biprotrusion & 28 & $22.4 \%$ \\
\hline Anterior Open Bite & 21 & $16.8 \%$ \\
\hline Lack of space & 7 & $5.6 \%$ \\
\hline Right Side Posterior Crossbite & 5 & $4 \%$ \\
\hline Left Side Posterior Crossbite & 4 & $3.2 \%$ \\
\hline Overjet & 4 & $3.2 \%$ \\
\hline Spacing & 4 & $3.2 \%$ \\
\hline Anterior Crossbite & 3 & $2.4 \%$ \\
\hline Posterior Crossbite & 3 & $2.4 \%$ \\
\hline Deep bite & 2 & $1.6 \%$ \\
\hline Edge-to-edge bite & 1 & $0.8 \%$ \\
\hline Total & 125 & $100 \%$ \\
\hline
\end{tabular}

Source: Research data 


\section{DISCUSSION}

Of the 264 schoolchildren who participated in the present study, 125 had malocclusion. Although it is a significant rate, a high percentage is expected in this age group given the intense dental changes occurring in this period. Epidemiological studies indicate that the majority of children with mixed dentition have some kind of morphological deviation in occlusion, with rates ranging from 66 to $96.8 \%{ }^{13-17}$. Such morphological deviations are defined as malocclusion.

In the current sample, the most frequent malocclusion was crowding, which was found in $34.4 \%$ of the cases and is within the range reported by other studies $-18.05 \%$ to $87 \%{ }^{18-21}$. This prevalence was already expected because, according to Peres ${ }^{9}$, such malocclusion is most often associated with Class I molar relationship. However, recent studies conducted in Nigeria by Costa ${ }^{22}$ and in India by Narayanan ${ }^{23}$ demonstrated a low occurrence of this problem $-5 \%$ and $3.2 \%$, respectively.

Biprotrusion was the second most prevalent problem in the present research occurring in $22.4 \%$ of the sample and the third highest prevalence found in the sample of another study ${ }^{19}$. Ramos ${ }^{24}$ points out that the incidence of this type of malocclusion is more common among black people. This may be due to the considerable ethnic variability between different parts of the country, which is one of the factors that may explain the findings in the aforementioned studies.

The present study presented a significant rate of $16.8 \%$ of anterior open bite. Such rate is similar to those found in the literature: $12.1 \%^{25}, 14.8 \%{ }^{22}, 22.6 \%{ }^{26}$ and $26 \%$. However, other studies have presented lower rates of $6.1 \%^{18}$ and $6.98 \%{ }^{23}$. Thus, the identification of the etiologic factors in this group would be necessary for the control of this problem given the high rates found in the present research.

Of all children examined, 5.6\% presented lack of space, which was the fourth most prevalent malocclusion and made this group more susceptible to crowding because primary teeth are natural dental space maintainers ${ }^{27}$. Thilander ${ }^{28}$ reports that the lack of space can be explained by the high incidence of dental caries and extraction of primary molars, which favored migration of the first permanent molar, tooth inclinations and rotations.

In the sagittal plane, the alteration found was the protrusion of the upper teeth ("overjet"), which appeared in $3.2 \%$ of the study population. However, contradictory results were found by Almeida ${ }^{13}$, Mansur $^{29}$ and Martins ${ }^{30}$, whose results may have been different because they included people with Class I, II and III malocclusion. Garbien ${ }^{18}$ reports that overjet is induced by external factors such as habits, posture of the lips, mouth breathing, among others; therefore, the absence of these characteristics may have influenced the results of the present study.

The presence of anterior crossbite occurred in $2.4 \%$ of the sample. Prevalence rates of anterior crossbite range from $2.2 \%$ to $12 \%$ in some studies ${ }^{5,17,32}$ depending on the age and ethnicity of the children studied and the inclusion of edge-to-edge incisor relationship.

In the transverse plane, right side and left side posterior crossbite and posterior crossbite (bilateral) occurred in a small percentage: $4 \%, 3.2 \%$ and $2.4 \%$, respectively. Authors ${ }^{32,33,35}$ have pointed out higher rates of posterior crossbite in primary and mixed dentition ranging from $8 \%$ to $16 \%$. A study has demonstrated that the large ethnic variability between different parts of the country coupled with environmental influences can change the facial profile ${ }^{35}$.

Spacing was prevalent in $3.2 \%$ of the sample. This prevalence was different in other studies that pointed out rates ranging from $35.05 \%{ }^{36}$ to $88.68 \%{ }^{19}$. Borges $^{37}$ mentions that excessive spacing between teeth is not commonly found in mixed dentition, except when there is a protrusion of incisors, which confirms the analysis of the present research.

Deep bite was less frequent in the study sample; it was found in only $1.6 \%$ of the children examined and is in line with the findings of another study ${ }^{38}$. The low percentage of $0.8 \%$ of edge-to-edge bite was expected as these occlusal characteristics are more commonly found in patients with class II and III malocclusion, respectively.

The assessment of oral abnormalities presented in the present study is a constant challenge given the aesthetic dissatisfaction and/or compromised function of the stomatognathic system ${ }^{3,4,7,8}$. Therefore, the dentist-surgeon plays a key role in the detection and early diagnosis of these oral abnormalities and therefore should take an active approach focused on the prevention and rehabilitation of such factors that have an impact on the daily lives of patients. 


\section{CONClusion}

Occlusal characteristics such as crowding, biprotrusion and anterior open bite were far more expressive than the others analyzed in the present study.

Despite the significant number of children affected by some type of malocclusion, it is important to note that these anomalies did not necessarily indicate a need for some intervention. However, the detection and early diagnosis of these oral conditions are crucial and the dentist-surgeon must take an active approach focused on the prevention of such factors that may have an impact on the daily lives of patients.

\section{REFERENCES}

[1] WHO. World Health Organization. Oral Health surveys: basic methods. 4 ed. Geneva: ORH/EPID; 1997.

[2] Normando D, Faber J, Guerreiro JF, Abdo Quintão CC. Dental occlusion in a split amazon indigenous population: genetics prevails over environment. PLoSOne. 2011; 6(12): 283-287.

[3] Proffit WR. Ortodontia contemporânea. 3.ed.Rio de Janeiro: Guanabara Koogan, 2002.

[4] Angle EH. Classification of Malocclusion. Rev Dental Cosmos. 1899; 41(1):248-264.

[5] Monini AC, Amaral RMP, Gandini MREAS, Gandini Jr LG. Prevalência das más oclusões em crianças na Clínica de Graduação da Faculdade de Odontologia de Araraquara - UNESP. RevOdontol UNESP. 2010; 39(3): 175-8.

[6] Gallão S, Martins LP, Faltin Jr K, Gandini Júnior LG, Pieri LV, Gaspar AMM, Bolini PDA. Diagnóstico e tratamento precoce da Classe III: relato de caso clínico. J Health Sci Inst. 2013; 31(1):733-740.

[7] Cavalcanti AL, Bezerra PKM, Alencar CRB, Moura C. Prevalence of Malocclusion in 6-12 Year-Old Schoolchildren in the City of Campina Grande, PB, Brazil. PesqBrasOdontopedClin Integr. 2008; 8(1):99-104.

[8] Schwertner A, Nouer PRA, Garbui IU, Kuramae M. Prevalência de maloclusão em crianças entre 7 e 11 anos em Foz do Iguaçu, PR. Rev Gaúcha Odont.2007;55(2):155-161.

[9] Peres KG, Traebert ESA, Marcenes W. Diferenças entre autopercepção e critérios normativos na identificação das oclusopatias. Rev Saúde Pública. 2002;36(2):230-236.

[10] Lima K.C. Prevalência e determinantes de oclusopatias nas dentições decíduas. 160. Dissertação (Mestrado em Ortodontia) - Programa de Pós-Graduação em Odontologia Preventiva e Social da UFRN, Faculdade Federal do Rio Grande do Norte, Natal.

[11] Onyeaso CO, Aderinokun GA, Arowojolu MO. The pattern of malocclusion among orthodontic patients seen in Dental Centre, University College Hospital, Ibadan, Nigéria. Afr. J Med MedSci. 2002; 31(3)207-211.

[12] BISHARA, S.E. Ortondontia. ed.São Paulo: Santos; 2004.

[13] Almeida MR, Pereira ALP, Almeida RR, Almeida-Pedrin RR, Silva Filho OG. Prevalência de má oclusão em crianças de 7 a 12 anos de idade. Dental Press J Orthod. 2011;16(4):123-31.

[14] Sousa RV, Pinto-Monteiro AKA, Martins CC, Granville-Garcia AF, Paiva SM. Maloclusion and socioeconomic indicators in primay dentition. Braz Oral Res. 2014;28(1):54-60.

[15] Sousa RV, Clementino MA, Gomes MC, Martins CC, GravilleGarcia AF, Paiva SM. Maloclusion and quality of life in Brazilian preschoolers. Eur J Oral Sci. 2014; 122(3):223-229.

[16] Góis EG, Vale MP, Paiva SM, Abreu MH, Serra-Negra JM, Pordeus IA. Incidence of malocclusion between primary and mixed dentitions among Brazilian children A 5-year longitudinal study. Angle Orthod. 2012; 82(3):495-500.

[17] Sousa JP, Sousa SA. Prevalência de má oclusão em escolares de 7 a 9 anos de idade do Polo 1 da Rede Municipal de Ensino em João Pessoa-PB. Rev Odontol UNESP. 2013; 42(2):117-123.

[18] Garbien AJI, Perin PCP, Garbin CAS, Lolli LF. Prevalência de oclusopatias e comparação entre a Classificação de Angle e o Índice de Estética Dentária em escolares do interior do estado de São Paulo-Brasil. Dental Press J Orthod. 2010; 15(4):94-102.

[19] Boeck EM, Pizzol KEDC, Navarro N, Chiozzini NM, Foschini ALR. Prevalência de maloclusão em escolares de 5 a 12 anos de rede municipal de ensino de Araraquara. Rev CEFAC, 2013; 15(5): 1270-1280. 
[20] Frazão MCA, Rodrigues VP, Pereira ALP. Prevalence of Malocclusion in Children of Public Schools in São Luís, MA, BRAZIL: Quantitative cross-sectional study. Rev Pesq Saúde, 2015; 16(1): 11-15.

[21] Farias ACR, Cangussu MCT, Ferreira RFA, Castellucci M. Occlusal characteristics and orthodontic treatment need in Black adolescents in Salvador/BA (Brazil): An epidemiologic study using the Dental Aesthetics Index. Dental Press J Orthod. 2013;18(1):34.e1-8.

[22] Costa OO, Aikins EA, Isiekwe GI, Adediran VE. Malocclusion and early orthodontic treatment requirements in the mixed dentitions of a population of Nigerian children. J Orthod Sci. 2016; 5(3):81-6.

[23] Narayanan RK, Jeseem MT, Kumar TA. Prevalence of Malocclusion among 10-12-year-old Schoolchildren in Kozhikode District, Kerala: An Epidemiological Study. Int J Clin Pediatr Dent. 2016; 9(1):50-5.

[24] Ramos SIF. Estudio epidemiológico de prevalencia de lãs maloclusiones em la población de raza caucasiana y negra del Puente de Baixa da Banheira-Lisboa. 2016. Tése (Doutorado em Ortodontia) Facultad de Odontología Departamento de Profilaxis, Odontopediatría y Ortodoncia, Universidad Complutense de Madrid, España.

[25] Machado DB, Brizon VS, Ambrosano GM, Madureira DF, Gomes VE, de Oliveira AC. Factors associated with the prevalence of anterior open bite among preschool children: a populationbased study in Brazil. Dental Press J Orthod. 2014; 19(5):103-9.

[26] Souza BS, Bichara LM, Guerreiro JF, Quintão CC, Normando D. Occlusal and facial features in Amazon indigenous: An insight into the role of genetics and environment in the etiology dental malocclusion. Arch Oral Biol. 2015; 60(9):1177-86.

[27] Cardoso L, Zembruski C, Fernandes DSC, Boff I, Pessin V. Avaliação da prevalência de perdas precoces de molares decíduos. Rev Bras Odontoped ClinIntegr 2005; 5(1):17-22.

[28] Thilander B, Pena L, Infante C, Parada SS, Mayorga C. Prevalence of malocclusion and orthodontic treatment need in children and adolescents in Bogota, Colombia. An epidemiological study related to different stages of dental development. Eur. J. Orthod., Oxford. 2001; 23,(2):153-167.

[29] Mansur SC. Prevalência de Má Oclusão em Crianças com Idade Escolar: Norte de Portugal. 2015. Dissertação (Mestrado em Ortodontia). Programa de Pós graduação da Faculdade de Ciências da Saúde da Universidade Fernando Pessoa, Porto, Liboa, Portugual.

[30] Martins MGA, Lima KC. Prevalence of occlusal status in 10-12-year-old schoolchildren in Ceará, Brasil. Oral Health PrevDent. 2009; 7(3):217-23.

[31] Boeck EM, Lunardi N, Pinto AS, Pizzol KEDC, Boeck Neto RJ. Occurrence of Skeletal Malocclusions in Brazilian Patients with Dentofacial Deformities. Braz Dent J 2011; 22(4): 340345.

[32] Paiva Lino A. Ortodontia Preventiva Básica. la Ed., Artes Médicas. 1992; 2:31-95.

[33] Silva Filho OG. Alterações cefalométricas ocorridas na dentadura mista após o uso do expansor fixo tipo quadriélice. Ortodontia. 1986; 19: 22-33.

[34] Vadiacaz GP, Roberts MW. Primary posterior crossbite. Diagnosticand treatment. The Joumal of clinical Pediatric Dentristy 1991;16(1).

[35] Garbien AJI, Perin PCP, Garbin CAS, Lolli LF. Prevalência de oclusopatias e comparação entre a Classificação de Angle e o Índice de Estética Dentária em escolares do interior do estado de São Paulo-Brasil. Dental Press J Orthod 2010; 15 (4):94-102.

[36] Carlos HM, Zanin L , Degan VV , Valdrighi HC , Venezian GC , Vedovello SAS. Malocclusion in schoolhildren aged 7-12 years old in Minas Gerais, Brazil. RevGaúch Odontol. 2016 ;64(2):164-170.

[37] Borges ASM. Abordagem Ortodôntica da Gestão de Espaço em Dentição mista. [Tese de Mestrado]. Porto: Universidade Fernando Pessoa. Faculdade de Ciência da Saúde; 2011.

[38] Brito DI, Dias PF, Gleiser R. Prevalência de más oclusões em crianças de 9 a 12 anos de idade da cidade de Nova Friburgo (Rio de Janeiro). Rev Dent Ortodon. Ortop Facial. 2009; 14(6):118124. 